\title{
BLOOD LEVELS OF ADENINE NUCLEOTIDES ${ }^{1}$
}

\author{
BY HARRY G. ALBAUM, THEODORE CAYLE, AND ARTHUR SHAPIRO \\ (From the Biology Research Laboratory, Brooklyn College, Brooklyn, N. Y.)
}

(Submitted for publication December 23, 1950; accepted, March 17, 1951)

\section{INTRODUCTION}

The metabolic significance of the adenine nucleotides $(1,2)$ and the reports of the therapeutic action of muscle adenylic acid and adenosine triphosphate in various pathological states (3-12) has stimulated interest in the possible mechanism of action in these compounds.

Recently a rapid reliable method was developed by one of us (13) for measuring total adenine, adenylic acid (AMP), adenosine diphosphate (ADP) and adenosine triphosphate (ATP). We have applied this method to the study of blood since it is the only human tissue which can be conveniently studied.

Before studies could be undertaken on pathologic bloods, we felt that normal bloods should be examined for total nucleotide content as well as for possible content of adenylic acid, adenosine diphosphate and adenosine triphosphate. That adenine nucleotides are present in blood has been known since 1914. The first completely adequate quantitative data are those of Buell in 1935 (14) who estimated total nucleotide nephelometrically after precipitating with uranium and then silver, from a neutralized trichloracetic acid filtrate. Apart from describing the procedure itself, Buell reported that the nucleotides are present principally in the red cells (indeed the value varies with the hematocrit); that the level for any one individual over a period of several months is fairly constant, and that the average value for males is about 11.5 mgm.\% and for females $10.0 \mathrm{mgm} . \%$ (expressed as adenine).

Our interest, as indicated above, was not only in the total nucleotide, but also in the constitution of the nucleotide. We also felt that the Buell procedure for estimating nucleotides was much too cumbersome. We, therefore, concentrated our attention on the preparation of filtrates which could be assayed directly.

1 This work was supported by a grant to Brooklyn College from the Ernst Bischoff Company, Ivoryton, Conn.
The procedure used in our work is a spectrophotometric assay on perchloric acid filtrates, using in modified form the enzyme techniques of Kalckar (15-17).

In addition to presenting observations on the concentration of the various nucleotides on a group of four normal subjects (three men and one woman) over a period of about eight months, data will be presented on the effects of intramuscular injections of muscle adenylic acid, adenosine triphosphate and yeast adenylic acid on the levels of the above compounds.

\section{ANALYTICAL PROCEDURE}

\section{a) Estimation of total adenine}

Total adenine nucleotide was assayed by drawing blood, initially under oxalate, and immediately deproteinizing 1 ml. with 4 volumes of cold $2 \%$ perchloric acid. The protein precipitate was washed with an additional volume of cold $2 \%$ perchloric acid. The combined supernatant solutions collected after centrifugation were adjusted to $\mathrm{pH}$ 7.0 and made to a final volume of $10 \mathrm{ml}$. One $\mathrm{ml}$. of filtrate was added to a tube containing $3.5 \mathrm{ml} . \mathrm{H}_{2} \mathrm{O}$ and 0.5 ml. M/10 phosphate buffer at $\mathrm{pH}$ 7.4. The resulting solution when read in the spectrophotometer shows an absorption maximum at $258 \mathrm{~m} \mu$, corresponding to the absorption maximum of adenine nucleotides in perchloric acid. Total nucleotide was calculated as adenine using muscle adenylic acid as a standard.

\section{b) Estimation of $A M P, A D P$ and $A T P$}

Adenylic acid, adenosine diphosphate and adenosine triphosphate were assayed in the same filtrates according to the procedure described by Albaum and Lipshitz (13), in the following way: One ml. aliquots of the filtrate were placed in three separate tubes. Into the first tube $0.5 \mathrm{ml}$. $0.1 \mathrm{M}$ malonate buffer $\mathrm{pH} 5.9,0.03 \mathrm{ml}$. of adenylic acid desminase (containing $15 \mu \mathrm{gm}$. protein $\mathrm{N}$ ) and water to make a final volume of $5.0 \mathrm{ml}$. were pipetted and the change in density in the spectrophotometer at $265 \mathrm{~m} \mu$ recorded at the end of 10 minutes. The second tube received buffer, water, $0.1 \mathrm{ml}$. $\mathrm{MgCl}_{2}$ (10 mgm./ml.), $0.01 \mathrm{ml}$. myokinase (containing $4 \mu \mathrm{gm}$. protein $\mathrm{N}$ ) and deaminase and again the change in density at $265 \mathrm{~m} \mu$ was recorded at the end of 10 minutes. To the third tube was added buffer, water, $\mathrm{MgCl}_{2}$, myokinase, $0.1 \mathrm{ml}$. $0.5 \mathrm{M}$ glucose, $0.01 \mathrm{ml}$. hexokinase (containing $7 \mu \mathrm{gm}$. protein $\mathrm{N}$ ) and the deaminase and once more the change in density determined. Any 
change in tube 2 over that occurring in tube 1 is due to the presence of ADP. Since only 1 mole of AMP is formed from 2 moles of ADP, the difference between tubes 1 and 2 is multiplied by a factor of 2 . The third tube records the change in density due to AMP, ADP and ATP. Since the concentration of AMP and ADP are now known (by reading the adenine due to these compounds from a standard curve derived from the change in density of known concentrations of these nucleotides) and the total adenine is known from tube 3, the difference between the AMP and ADP adenine and the total adenine gives the value for the ATP adenine.

The reactions discussed above are represented by the following equations :

(1) AMP $\stackrel{\text { adenylic acid deaminase }}{\longrightarrow}$ Inosinic Acid

(2) $2 \mathrm{ADP} \stackrel{\text { myokinase }}{\longrightarrow} \mathrm{ATP}+\mathrm{AMP}$

(3) ATP + glucose $\stackrel{\text { hexokinase }}{\longrightarrow}$ ADP + glucose-6phosphate

Before experiments were undertaken on the distribution of the compounds, several preliminary runs were carried out to see whether the method as described was reliable, i.e., could added nucleotide be recovered and measured? The results of one such experiment are shown in Table I. The total nucleotide accountable for as AMP, ADP and ATP in this sample of blood was $6.4 \mu \mathrm{gm}$. It is apparent that added ATP can be recovered indicating that the method is reliable.

Early in our studies on the concentration of the various nucleotide fractions in oxalated human blood, it was found that ATP content decreased significantly within the first hour, though not in the first five minutes. For this reason, in the early work which was done on oxalated blood, the samples were pipetted into perchloric acid within one minute of withdrawal. To avoid the inconvenience of this procedure, the stability of the nucleotide in heparinized blood was investigated. Table II shows the percentage of total purine found in the ATP, AMP and ADP fractions, respectively, in freshly drawn blood, and in the same blood samples after 90 minutes. The experiment was run at room temperature and at $37^{\circ} \mathrm{C}$. in the presence of a mixture of potassium oxalate and ammonium oxalate, of which the oxalate concentration was $112 \mathrm{mgm}$. \%, and in the presence of $5 \mathrm{mgm}$. \% of heparin. It is clear that the ATP is very significantly split to ADP and AMP in oxalated blood, while it is quite stable in the heparinized blood.

Adenylic acid deaminase (Schmidt's deaminase) was

\section{TABLE I}

Recovery of ATP when added to perchloric acid filtrate of blood

1. Total AMP, ADP, and ATP found in blood sample = $6.4 \mu \mathrm{gm}$.

2. ATP added to blood sample $=8.2 \mu \mathrm{gm}$.

3. Total AMP, ADP, and ATP in blood and added ATP calculated $(1+2)=14.6 \mu \mathrm{gm}$.

found $\quad=14.3 \mu \mathrm{gm}$.
TABLE II

Effect of standing on adenine nucleotides in blood

\begin{tabular}{|c|c|c|c|c|c|}
\hline \multirow{2}{*}{$\begin{array}{c}\text { Temper- } \\
\text { ature }\end{array}$} & & \multirow{2}{*}{ Time } & \multicolumn{3}{|c|}{$\%$ of total purine as } \\
\hline & & & ATP & AMP & ADP \\
\hline \multirow{2}{*}{ Room } & Oxalated blood & $\begin{array}{c}\min . \\
0 \\
90\end{array}$ & $\begin{array}{l}68 \\
15\end{array}$ & $\begin{array}{r}0 \\
28\end{array}$ & $\begin{array}{r}0 \\
25\end{array}$ \\
\hline & Heparinized blood & $\begin{array}{r}0 \\
90\end{array}$ & $\begin{array}{l}58 \\
59\end{array}$ & $\begin{array}{l}0 \\
0\end{array}$ & $\begin{array}{l}0 \\
4\end{array}$ \\
\hline \multirow{2}{*}{$37^{\circ} \mathrm{C}$. } & & $\begin{array}{r}0 \\
90\end{array}$ & $\begin{array}{l}40 \\
12\end{array}$ & $\begin{array}{r}0 \\
20\end{array}$ & $\begin{array}{l}5 \\
7\end{array}$ \\
\hline & Heparinized blood & $\begin{array}{r}0 \\
90\end{array}$ & $\begin{array}{l}39 \\
44\end{array}$ & $\begin{array}{l}\mathbf{0} \\
\mathbf{0}\end{array}$ & $\begin{array}{l}5 \\
0\end{array}$ \\
\hline
\end{tabular}

prepared according to the method of Kalckar (15) ; myokinase, according to Colowick and Kalckar (18); hexokinase was prepared in partially pure form according to the method of Berger, Slein, Colowick and Cori (19) through step No. 3 (fractionation with ethanol at $0^{\circ} \mathrm{C}$.) of the isolation procedure. The enzymes were kept in a deep freeze and were found to be stable over long periods of time.

Muscle adenylic acid used for injection was supplied by the Ernst Bischoff Co., Ivoryton, Conn. as My-B-Den (1 $\mathrm{ml}$. ampules containing $20 \mathrm{mgm}$. as the sodium salt). In some experiments ampules containing $100 \mathrm{mgm} . / \mathrm{ml}$. were used. ATP was also obtained from the Ernst Bischoff Co. and was administered as a solution of the sodium salt.

\section{EXPERIMENTAL}

\section{Total nucleotide content of blood}

The total nucleotide content of the blood of the four subjects used in the experiments expressed as mgm. \% adenine are shown in Figure 1 (closed circles). Several conclusions may be drawn from these data: 1.) While there is some variability in total nucleotide, the levels remain fairly uniform over a period of about eight months. The variability is no greater than one finds in the levels of other blood constituents under normal conditions. 2.) The levels obtained are similar to those obtained by Buell using the nephelometric procedure, so that we appear to be measuring the same thing that Buell measured.

\section{Nucleotide present as $A M P, A D P$ and $A T P$}

That portion of the total nucleotide accountable for as AMP, ADP and ATP is also shown in Figure 1 (open circles). It is immediately clear that the level of these compounds shows considerably more variation than does the total nucleotide. 
They may vary anywhere between 30 and $90 \%$ of the total nucleotide. Some of the early samples were collected before breakfast, the later ones after breakfast; and there appeared to be no consistent difference.

To further illustrate the difference in variability between the values for the total purine and those for the known nucleotide (AMP, ADP and ATP) we have calculated the mean, standard deviation and coefficient of variability for a large number of individual determinations $(n=78)$. For the total purine the following values were obtained: $\mathrm{m}=$ $10.5 \mathrm{mgm} . \%$, the standard deviation 0.84 , the coefficient of variability $8.0 \%$. The corresponding values for the known nucleotide were $\mathrm{m}=6.0$ mgm. $\%$, the standard deviation 1.58 , and the coefficient of variability $26.5 \%$.

\section{Effect of injection of adenylic acid}

The fact that the amount of nucleotide present as AMP, ADP and ATP is variable from day to day (see Figure 1), and that the total nucleotide remains fairly uniform, suggests that the former are individually in some kind of loose equilibrium with the total nucleotide. Can this equilibrium be shifted, e.g., by the injection of adenylic acid? In these experiments $20 \mathrm{mgm}$. ampules of muscle adenylic acid as the sodium salt (My-B-Den) were used. Blood was taken from the antecubital vein, and immediately thereafter the contents of an adenylic acid ampule were injected into the other arm intramuscularly. Additional blood samples were withdrawn from the first arm 30, 60 and 90 minutes after the injection. The results of three typical runs are shown in Table III. It should be noted that most of the blood samples contained ADP and ATP, but no adenylic acid initially. After injection in all cases the ADP decreased and the ATP increased. The ATP level in two of the three cases began to fall at the end of 60 minutes and adenylic acid appeared. The total purine accountable for as AMP, ADP and ATP approached the value for the total nucleotide. In many cases the increases obtained in the known AMP, ADP and ATP fractions were not as marked as those shown, but they almost always occurred. In one case no increase was obtained in the first run, though in a subsequent run it did occur. ${ }^{2}$

\footnotetext{
2 Since this paper went to press, the response of five additional normal subjects to the injection of muscle adenylic acid was tested. Four of the five showed a response similar to that in Table III. One subject showed no change in blood nucleotide. A later run on the same subject also gave a negative response.
}

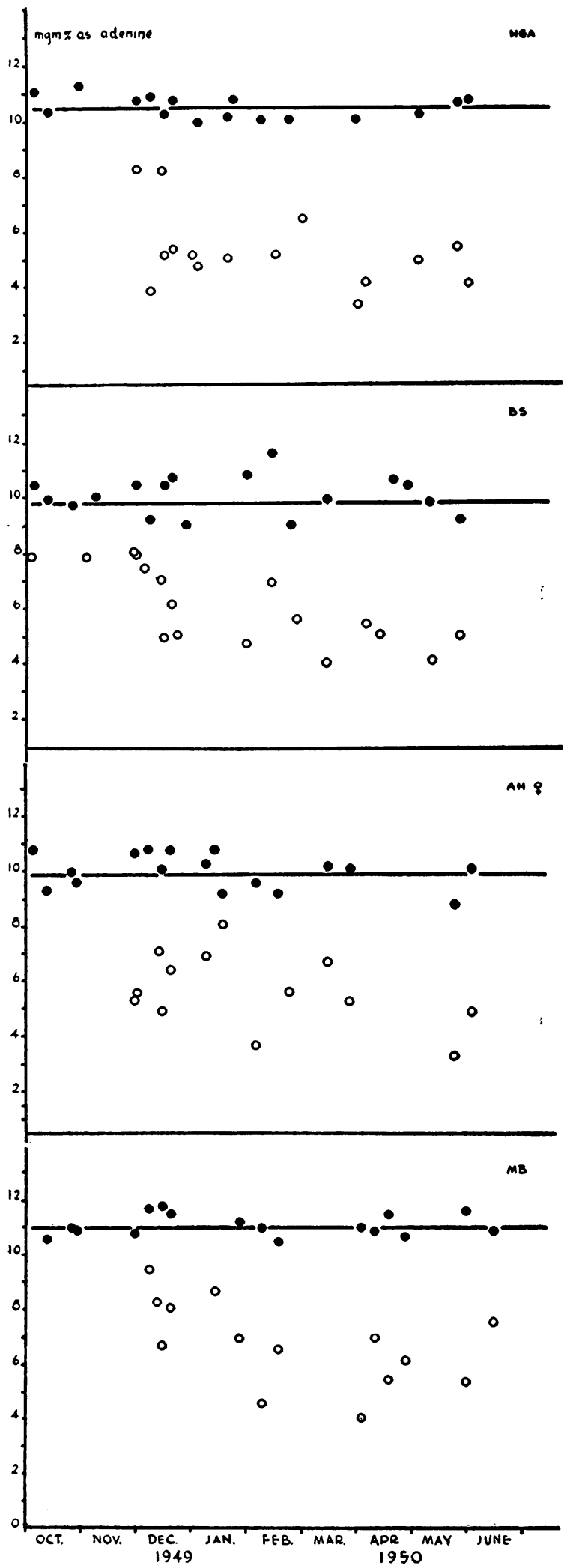

Fig. 1. Total Purine (Closed Circles) and Nucleotides Present as AMP, ADP and ATP (Open Circles) for a Group of Four Subjects (Three Men and One Woman) over a Period of Eight Months 
TABLE III

Effect of intramuscular injection of 5-adenylic acid: $20 \mathrm{mgm}$. (My-B-Den) on blood nucleotides ( $A M P, A D P, A T P)$

\begin{tabular}{|c|c|c|c|c|}
\hline$\underset{\text { (minutes) }}{\text { Time }}$ & AMP & ADP & ATP & Total \\
\hline \multicolumn{5}{|c|}{ AH $1 / 18 / 50$-Total purine $9.2 \mathrm{mgm} . \%$} \\
\hline $\begin{array}{r}0 \\
\rightarrow 30 \\
60 \\
90\end{array}$ & $\begin{array}{l}0.0 \\
0.0 \\
0.0 \\
1.2\end{array}$ & $\begin{array}{l}6.5 \\
4.5 \\
0.8 \\
0.0\end{array}$ & $\begin{array}{l}1.7 \\
4.3 \\
8.0 \\
8.0\end{array}$ & $\begin{array}{l}8.2 \\
8.3 \\
8.8 \\
9.2\end{array}$ \\
\hline
\end{tabular}

HA $1 / 20 / 50$-Total purine $10.2 \mathrm{mgm} . \%$

\begin{tabular}{r|r|r|r|r}
\hline 0 & 0.0 & 4.1 & 1.0 & 5.1 \\
30 & 0.0 & 3.4 & 4.4 & 7.8 \\
60 & 0.0 & 0.0 & 10.0 & 10.0 \\
90 & 2.4 & 0.0 & 7.1 & 9.5 \\
\hline
\end{tabular}

MB 1/23/50-Total purine $11.2 \mathrm{mgm} . \%$

\begin{tabular}{r|l|l|l|r}
\hline 0 & 0.0 & 3.7 & 3.3 & 7.0 \\
$\rightarrow 30$ & 0.0 & 3.4 & 6.8 & 10.2 \\
60 & 0.0 & 2.5 & 7.6 & 10.1 \\
90 & 1.1 & 3.4 & 4.0 & 8.5 \\
\hline
\end{tabular}

BS 3/13/50-Total purine $10.0 \mathrm{mgm}$. \%

\begin{tabular}{r|l|l|l|l}
\hline$\rightarrow 0$ & 0.0 & 0.0 & 4.1 & 4.1 \\
30 & 0.0 & 0.0 & 7.7 & 7.7 \\
60 & 0.0 & 0.0 & 9.1 & 9.1 \\
90 & 0.0 & 0.0 & 7.7 & 7.7 \\
\hline
\end{tabular}

The magnitude of the increases obtained was entirely out of proportion to the amount of adenylic acid injected. The increase in concentration of nucleotide expected if all of the injected nucleotide were simultaneously to appear in the blood would

TABLE IV

Effect of intramuscular injection of 5-adenylic acid: $100 \mathrm{mgm}$. (My-B-Den) on blood nucleotides

\begin{tabular}{l|l|l|l|l}
\hline $\begin{array}{c}\text { Time } \\
\text { (minutes) }\end{array}$ & AMP & ADP & ATP & Total \\
\hline
\end{tabular}

HA 3/1/50 Initial total purine $10.1 \mathrm{mgm} .-30$ minute total purine $11.2 \mathrm{mgm}$. \%

\begin{tabular}{r|l|l|l|l}
\hline 0 & 0.0 & 0.9 & 5.7 & 6.6 \\
30 & 0.2 & 0.0 & 9.0 & 9.2 \\
60 & 0.3 & 0.0 & 7.2 & 7.5 \\
90 & 0.0 & 0.9 & 5.9 & 6.8 \\
\hline
\end{tabular}

MB 2/31/50 Initial total purine $10.2 \mathrm{mgm}$. \%-30 minute total purine $12.0 \mathrm{mgm}$. \%

\begin{tabular}{r|l|l|l|l}
\hline 0 & 0.5 & 0.0 & 6.1 & 6.6 \\
30 & 0.0 & 0.0 & 9.6 & 9.6 \\
60 & 0.3 & 0.5 & 8.3 & 9.1 \\
90 & 0.3 & 4.6 & 4.3 & 9.2 \\
\hline
\end{tabular}

TABLE V

Effect of intramuscular injection of 3-adenylic acid (yeast): 20 mgm. on blood nucleotides

\begin{tabular}{|c|c|c|c|c|}
\hline $\begin{array}{c}\text { Time } \\
\text { (minutes) }\end{array}$ & AMP & ADP & ATP & Total \\
\hline RS & \multicolumn{4}{|c|}{ Total purine-12.1 mgm. $\%$} \\
\hline $\begin{array}{r}\rightarrow \\
30 \\
60 \\
90\end{array}$ & $\begin{array}{l}0 \\
0 \\
0 \\
0\end{array}$ & $\begin{array}{l}0 \\
0 \\
0 \\
0\end{array}$ & $\begin{array}{l}9.0 \\
9.0 \\
9.3 \\
9.3\end{array}$ & $\begin{array}{l}9.0 \\
9.0 \\
9.3 \\
9.3\end{array}$ \\
\hline LIC & \multicolumn{4}{|c|}{ Total purine $-8.2 \mathrm{mgm} . \%$} \\
\hline $\begin{array}{r}0 \\
\rightarrow 30 \\
60 \\
90\end{array}$ & $\begin{array}{l}0 \\
0 \\
0 \\
0\end{array}$ & $\begin{array}{l}0 \\
0 \\
0 \\
0\end{array}$ & $\begin{array}{l}4.2 \\
4.5 \\
4.8 \\
4.8\end{array}$ & $\begin{array}{l}4.2 \\
4.5 \\
4.8 \\
4.8\end{array}$ \\
\hline
\end{tabular}

not exceed 0.1 to $0.2 \mathrm{mgm} . \%$. The effect, therefore, appears to be an indirect one of some kind. This is further indicated by the fact that when a $100 \mathrm{mgm}$. dose of muscle adenylic acid was in-

TABLE VI

Blood cell levels of adenine nucleotides after addition of 5-adenylic acid (10 mgm. \%) to whole blood in vitro

\begin{tabular}{c|l|c|c|c}
\hline \hline $\begin{array}{c}\text { Time } \\
\text { (minutes) }\end{array}$ & AMP & ADP & $\begin{array}{c}\text { ATP } \\
(\boldsymbol{m g m} . \%)\end{array}$ \\
\hline \multirow{2}{*}{0} & Control & 0.0 & 0.0 & 5.9 \\
& Experimental & 0.0 & 0.0 & 5.8 \\
& Control & 0.0 & 0.0 & 5.5 \\
& Experimental 10 mgm. & & & \\
\% AMP & Control & 0.0 & 0.0 & 5.3 \\
& Experimental & 0.0 & 0.0 & 5.2 \\
& Control & 0.0 & 0.0 & 5.3 \\
& Experimental & 0.0 & 0.0 & 5.8 \\
& 0.0 & 0.0 & 5.8 \\
\hline
\end{tabular}

jected (see Table IV), the increase obtained was no greater than that obtained with the $20 \mathrm{mgm}$. dose. With the $100 \mathrm{mgm}$. dose there was a transitory increase in total purine which was not ob-

TABLE VII

Effect of intramuscular injection of ATP (equivalent to $20 \mathrm{mgm}$. $A M P$ )

\begin{tabular}{|c|c|c|c|c|}
\hline $\begin{array}{c}\text { Time } \\
\text { (minutes) }\end{array}$ & AMP & ADP & ATP & $\begin{array}{c}\text { Total } \\
(m g m . \%)\end{array}$ \\
\hline $\mathrm{AH}$ & \multicolumn{4}{|c|}{ Total purine-10.1 mgm. $\%$} \\
\hline $\begin{array}{r}0 \\
\quad 30 \\
60 \\
90\end{array}$ & $\begin{array}{l}0.0 \\
0.0 \\
0.0 \\
0.0\end{array}$ & $\begin{array}{l}0.0 \\
0.0 \\
0.0 \\
0.0\end{array}$ & $\begin{array}{l}5.3 \\
7.0 \\
7.9 \\
7.2\end{array}$ & $\begin{array}{l}5.3 \\
7.0 \\
7.9 \\
7.2\end{array}$ \\
\hline
\end{tabular}


TABLE VIII

In vitro destruction of $A T P$ by whole blood-ATP added, 5.2 mgm. \%

\begin{tabular}{c|c|c|c}
\hline \hline $\begin{array}{c}\text { Time } \\
\text { (minutes) }\end{array}$ & AMP & ADP & ATP \\
\cline { 1 - 2 } 0 & 0.7 & 0.0 & 4.5 \\
15 & 1.3 & 0.6 & 3.3 \\
30 & 1.3 & 0.9 & 3.0 \\
60 & 1.8 & 0.6 & 2.8 \\
90 & 3.0 & 0.0 & 2.2 \\
\hline
\end{tabular}

served with the $20 \mathrm{mgm}$. dose. Within 60 minutes the level had returned to normal.

The possibility that the observed effects of muscle adenylic acid on blood nucleotide levels was due to psychogenic or other adventitious factors, was excluded by the results of experiments carried out under identical conditions, but substituting yeast adenylic acid for muscle adenylic acid (Table V).

That the effect of the injected adenylic acid was an indirect one was demonstrated by adding AMP directly to whole blood. The experiment was carried out in the following way. Blood was removed under heparin from the antecubital vein of one of the subjects. Ten $\mathrm{ml}$. of this blood were placed in each of two tubes. One ml. from each tube was removed and centrifuged; the plasma was poured off and the cells deproteinized as before. The filtrates were assayed for AMP, ADP and ATP. To one of the blood samples was then added sufficient AMP to produce an increase of nucleotide of $10.0 \mathrm{mgm} . \%$. At the end of one, three and 15 minutes, $1 \mathrm{ml}$. samples were removed, centrifuged and deproteinized as before and once more AMP, ADP and ATP were determined.

The results are shown in Table VI. It is apparent that not only does added AMP produce no effect on the distribution of other nucleotides in the cell, but it does not even appear to penetrate the red blood cell. Experiments carried out over a longer time interval gave similar results.

The injection of ATP in a dose containing the same adenine content as a My-B-Den ampule yields results which are similar to that obtained with the latter compound (Table VII). That the effect in this case may be due to the adenylic acid in ATP, rather than ATP itself is suggested by the observation that ATP placed in contact with blood is rapidly split (Table VIII).

\section{DISCUSSION}

In spite of the importance of the adenine nucleotides in so many critical life processes, this is the first report which presents data on the relative concentration of the different nucleotides in human blood. It is now possible to compare these values with corresponding values in different pathological states. Such experiments are already in progress.

From a medical standpoint it would be of great interest to know whether the reported clinical therapeutic effects of adenylic acid as well as earlier reports on ATP, are mediated through effects of this type. It would be especially interesting to know whether changes similar to those in the blood cells occur in other cells of the body (myocardium, central nervous system, nerves, glands, etc.), and whether, perhaps, the as yet unexplained actions of substances other than adenylic acid may operate through similar mechanisms. Comparison of the behavior of the adenine nucleotides in normal individuals with similar processes in various disease states may explain some of the puzzling phenomena in clinical medicine, and may possibly provide a mechanism for some of the "diseases of unknown etiology."

One point bears special emphasis : the lability of the equilibrium of the total nucleotide. We have shown that under certain conditions we can shift the balance in favor of ATP. Very recently Leder, Perlzweig, and Handler (20) have shown that when nicotinamide is added to washed erythrocytes, an eight to ten fold increase occurs in a pyridine nucleotide which behaves like DPN in a fluorometric assay. Since DPN contains adenylic acid, the latter must be derived from the same labile reservoir which under our conditions is converted to ATP. This indicates that the nucleotide may be "shifted" to compounds other than ATP under appropriate conditions.

\section{SUMMARY}

1. A technique is described for measuring the total adenine nucleotide as well as the adenylic acid, adenosine diphosphate, and adenosine triphosphate content of blood. The total nucleotide remains fairly uniform over long periods of time, while the known nucleotide (AMP, ADP and 
ATP) shows considerable variation from week to week.

2. In freshly drawn blood the level of known nucleotide is maintained for at least 90 minutes when the blood is drawn under heparin; when drawn under oxalate, the ATP is rapidly converted to ADP and AMP.

3. The magnitude of the ATP level of blood is increased by the intramuscular injection of $\mathrm{My}-\mathrm{B}$ Den (muscle adenylic acid) and ATP, but not by yeast adenylic acid. The effect obtained appears to be an indirect one since larger doses produce no more of an increase than do lower doses. That the effect is indirect is further borne out by the observation that nucleotide (AMP) added directly to blood does not appear to enter the cells.

\section{REFERENCES}

1. Lipmann, F., Metabolic generation and utilization of phosphate bond energy, in Advances in Enzymology, edited by Nord, F. F., and Werkman, C. H. Interscience Publishers, Inc., New York, 1941, Vol. I, p. 99.

2. Baldwin, E., Dynamic Aspects of Biochemistry. Cambridge University Press, London, 1947.

3. Rottino, A., Relief from pruritus following upon administration of adenylic acid. Proc. Soc. Exper. Biol. \& Med., 1949, 71, 379.

4. Rottino, A., Effect of adenylic acid therapy upon pruritus due to Hodgkin's and other diseases. Cancer, 1950, 3, 272.

5. Rottino, A., Boller, M., and Pratt, G. H., Therapeutic action of muscle adenylic acid on ulcers and dermatitis associated with varicose or phlebitic veins; preliminary report. Angiology, 1950, 1, 194.

6. Carlström, B., and Lövgren, O., Die Behandlung chronischer Polyarthritis mit Adenosintriphosphorsäure. Acta med. Scandinav., 1943, 115, 568.

7. Carlström, B., and Lövgren, O., Clinical observations on the treatment of rheumatic disease conditions with myoadenylic acid and adenosine pyrophosphoric acid. Acta med. Scandinav., 1942, 110, 230.
8. Herbrand, W., Die biologische und pharmako-therapeutische Bedeutung der körpereigenen Muskeladenosinphosphorsäure. Deutsche med. Wchnschr., 1937, 63, 1841.

9. Lövgren, O., Einige Bemerkungen über Hypocitricämien. Klin. Wchnschr., 1942, 21, 612.

10. Pezold, K., Therapeutische Versuche zur Förderung der örtlichen Genebsdurchblutung beim Ulcus cruris varicosum. Deutsche med. Wchnschr., 1942, 68, 116.

11. Roth, G. M., and Brown, G. E., Effect of tissue extracts on intermittent claudication. M. Clin. North America, 1934, 18, 609.

12. Spies, T. D., Bean, W. B., and Vilter, R. W., Adenylic acid in human nutrition. Ann. Int. Med., 1940, 13, 1616.

13. Albaum, H. G., and Lipshitz, R., Determination of adenosine triphosphate based on deamination rates. Arch. Biochem., 1950, 27, 102.

14. Buell, M. V., The adenine nucleotide content of human blood. I. Determination and content. J. Biol. Chem., 1935, 108, 273.

15. Kalckar, H. M., Differential spectrophotometry of purine compounds by means of specific enzymes. I. Determination of hydroxypurine compounds. J. Biol. Chem., 1947, 167, 429.

16. Kalckar, H. M., Differential spectrophotometry of purine compounds by means of specific enzymes. II. Determination of adenine compounds. J. Biol. Chem., 1947, 167, 445.

17. Kalckar, H. M., Differential spectrophotometry of purine compounds by means of specific enzymes. III. Studies of the enzymes of purine metabolism. J. Biol. Chem., 1947, 167, 461.

18. Colowick, S. P., and Kalckar, H. M., The role of myokinase in transphosphorylations. I. The enzymatic phosphorylation of hexoses by adenyl pyrophosphate. J. Biol. Chem., 1943, 148, 117.

19. Berger, L., Slein, M. W., Colowick, S. P., and Cori, C. F., Isolation of hexokinase from baker's yeast. J. Gen. Physiol., 1946, 29, 379.

20. Leder, I. G., Perlzweig, W. A., and Handler, P., Synthesis of unusual quantities of pyridine nucleotides by human erythrocytes, in vitro. Federation Proc., 1950, 9, 397. 